ISSN 1397-4831

WORKING PAPER 03-24

Valérie Smeets and Frédéric Warzynski

Job Creation, Job Destruction and Voting Behavior in Poland

Department of Economics

Aarhus School of Business 


\title{
Job Creation, Job Destruction and Voting Behavior in Poland*
}

\author{
Valérie Smeets ${ }^{\dagger}$ and Frédéric Warzynski ${ }^{\ddagger}$
}

\begin{abstract}
This paper analyzes the effect of job creation and job destruction on the voting patterns of individuals in Poland during the 1997 and 2001 parliamentary elections. First, we link the votes for the left wing party to the unemployment rate and the job creation and destruction rates in the constituency. We show that the job destruction rate and unemployment rate has a positive effect on the votes for the SLD, while the job creation rate has a negative effect. Second, we look at the effect of the change in job creation and job destruction rates on the change in the votes for individual candidates. We find that incumbents from the former right wing coalition received less votes if excess job reallocation had increased in their constituency. Therefore, the paper provides evidence that job flows have a strong impact on voting patterns and that the balance between the positive and negative effects of reforms determine to a large extent the political outcome.
\end{abstract}

JEL Codes: D72, P26

Keywords: job creation, job destruction, voting behavior, gradualism

\footnotetext{
${ }^{*}$ We are grateful to Professor Frances Millard for providing the voting data. The paper benefitted from comments by participants at the WDI-ZEI conference "Political Economy of Transitions: Job Creation and Job Destruction". All remaining errors are ours.

${ }^{\dagger}$ Aarhus School of Business and ECARES, Université Libre de Bruxelles

${ }^{\ddagger}$ Corresponding author. Address: Aarhus School of Business, Department of Economics, Prismet-2, Silkeborgvej 8000 Aarhus C Denmark; email: fwa@asb.dk
} 


\section{Introduction}

In the 1940s, the famous Austrian economist Joseph Schumpeter introduced the notion of creative destruction in his book, Capitalism, Socialism and Democracy. In his words:

"The fundamental impulse that keeps the capital engine in motion comes from the new consumers' goods, the new methods of production and transportation, the new markets..[The process] incessantly revolutionizes from within, incessantly destroying the old one, incessantly creating a new one. This process of Creative Destruction is the essential fact of capitalism.", Schumpeter (1942)

Theoretical and empirical work has rediscovered this notion at the beginning of the 1990s, leading to a theory of Schumpeterian growth, formalizing the main ideas in Schumpeter's work.

There is now considerable evidence that the reallocation process has important efficiency consequences and contributes significantly to productivity growth. For example, in the US, half of total factor productivity growth over the course of a decade can be accounted for by the reallocation of outputs and inputs away from less productive to more productive businesses (Haltiwanger, 2000). In Poland, Warzynski (2003) found a significant and positive relationship between labor productivity growth and excess job reallocation.

However, the process of creative destruction can also have important social consequences if workers are not reallocated smoothly from old jobs to the new ones. If individuals have outdated skills, it is likely that finding a new employer will be very difficult.

In transition countries, resources were allocated inefficiently and the production processes were in many cases obsolete. When trade was liberalized and foreign investment permitted, firms lost market share and major restructuring programs were launched, leading to a considerable amount of job displacements.

Transition inevitably led to the constitution of a group of winners and losers. An intense debate at the beginning of transition opposed those who favored a big bang approach to reforms, to those defending the more gradualistic approach (see Dewatripont and Roland, 1995). While the former 
stressed the window of opportunities which allowed radical reforms to be undertaken, the latter focused on the importance of political constraints. In a democratic society, politicians are accountable for the consequences of reforms. Therefore, a big bang strategy will create a large proportion of losers, who will oppose further reforms. Gradualism will then be a more viable strategy.

On the one hand, new opportunities allowed the creation of new firms, which started developing new products. On the other hand, individuals who were working in firms and who lost their jobs were very dissatisfied with the result of the reforms. During election time, losers from the transition process have the right to translate their dissatisfaction in their votes. Therefore, very high levels of job destruction are likely to be associated with a high level of votes for parties opposing fast reforms, while higher job creation will be associated with more votes for the reforming parties, as individuals working in new firms are more likely to bring their votes to the parties that created the new opportunities.

This paper analyzes the effect of job creation and job destruction on the voting patterns of individuals in Poland during the 1997 and 2001 parliamentary elections. In September 2001, Poles voted massively for the socialists, ending four years of right wing government. We test whether the economic deterioration between 1997 and 2001 played a role in explaining this result.

A small literature has investigated the effect of economic variables (influenced by economic reforms) on the voting behavior in transition. Fidrmuc (2000) analyzes whether the consequences of economic reforms determine the political support for the reforming parties. In his paper, elections play the role of referenda on the speed of reforms, rather than rewards or punishments. He finds a strong and positive association between regional unemployment rate and votes for the left wing parties opposing reforms. The level of entrepreneurial activity, creating new employment opportunities, had the opposite effect, favoring the parties pushing for further reforms. Jackson et al. (2003) argue that the creation of new firms is accompanied by the emergence of a part of society that supports reforms, as their fate is linked to the success of the new entrepreneurial firms. They find evidence confirming this theory during the 1993 and 1997 Polish elections.

We analyze voting behavior at two levels. First, we link the votes for the left wing party to the unemployment rate and the job creation and 
destruction rates in the constituency. Second, we look at the influence of the change in job creation and job destruction rates on the change in the votes for individual candidates.

We find that job flows have a strong impact on voting patterns. In our regional analysis, we show that the job destruction rate and unemployment rate have a positive effect on the votes for the SLD, while the job creation rate has a negative effect. In our analysis of votes for individual candidates, we find that incumbents from the former right wing coalition received less votes if excess job reallocation had increased in their constituency. Therefore, the balance between the positive and negative effects of reforms determine to a large extent the political outcome.

The paper is structured as follows. Section 2 and 3 briefly reviews the economic and political environment in Poland before the 2001 elections. Section 4 describes the different elements of our database, constructed from many different sources. Section 5 presents the empirical methodology, while section 6 shows and discusses the results and their limitations. Section 7 introduces our research agenda. Finally, section 8 concludes.

\section{Economic Situation in Poland}

Until recently, Poland has been considered as one of the most successful transition country. It was the first country to emerge from the transitionary recession as early as 1993, and it has been growing at a very fast pace since. Unemployment which had been high in the mid nineties was declining and reached a low in August 1998, going for a short while under $10 \%$.

In 2000 and 2001, however, GDP growth has declined dramatically, falling to only $1 \%$, mostly due to a drop in investment activity. Unemployment had started rising anticipatively and reached a new record high in February 2003 with a level of $18.8 \%$ (see Figure 1).

\section{$<$ Insert figure 1>}

However, there are large regional disparities. Some regions have been affected much more by the social consequences of restructuring, mostly in areas where industries were hurt following trade liberalization. On the opposite, unemployment in cities has remained much lower. Unemployment 
has also been rising dramatically in all subsets.

$<$ Insert table 1>

\section{Political Situation in Poland}

After the 1997 elections, the right wing parties returned to power after four years of left wing government. The Solidarity Election Action (AWS) won 201 seats and the Freedom Union (UW) 60 seats over 460 available, putting them in an apparent comfortable position. However, opinion differences led to an exit of the UW from the coalition in the Summer of 2000, a few months before the easy reelection of Aleksander Kwasniewski as President of the Republic of Poland. The AWS and the UW then started collapsing, losing many members to the new formations like the Civic Platform (PO) or Law and Justice (PiS). Meanwhile, the Alliance of the Democratic Left (SLD) made a pre-electoral alliance with a smaller left wing party, Unia Pracy (UP, Labor Union)

In 2001, the left wingers came back to power, holding a much stronger position as the SLD-UP won $47 \%$ of the seats, while the PSL won $9.1 \%$. These two parties agreed to form a majority government. The parties in the opposition had all been formed in 2001, and resulted from a major recomposition of the political landscape. The Civic Platform was probably considered as the most pro-market, while Law and Justice had its roots in the Catholic trade unionist anti-communist wing of the Solidarity movement. The League of Polish Families had a strong nationalistic and catholic image while Self Defense was labelled as populist and more oriented towards those left behind with the reforms.

$$
<\text { Insert table 2> }
$$

\section{Data}

\subsection{Votes for individuals}

The votes for each individual candidate at the 1997 and 2001 elections for the Sejm were made available online as part of the project "Political Transformation and the Electoral Process in Post-Communist Europe" at the 
University of Essex. The dataset provides two important measures of performance: the number of votes and whether the candidate was elected. For the 1997 election, we also know whether the candidate was elected in his constituency or through the national list.

The name of the candidate is associated to his constituency (okręg wyborczy) and his party. The database also provides information about the place of the candidate on the party list, the age and the gender of the candidate and his profession.

We merged the two waves of elections and could define 12682 individuals. We focus our attention on the 1192 individuals who have been candidates during the two rounds ${ }^{1}$. Our dataset also contains information about 11490 individuals who only ran in one year, 5210 in 1997 and 6280 in 2001.

In 1997, there were 52 constituencies and 49 voivodships (wojewodztwo). In 1999, Poland introduced a major reform, reducing the number of voivodships to 16 . For the 2001 elections, the number of constituencies was reduced to 41 .

\subsection{Votes by constituency}

The dataset provides the votes by party and by constituency, as well as the number of seats awarded to the party, the number of seats allocated to the constituency, the number of registered voters, the number of actual voters, the number of valid votes and the turnout rate.

The data were cross-checked with official information provided by the Państwowa Komisja Wyborcza (PKW).

\subsection{Firm level dataset}

Our Polish firm level dataset is extracted from Amadeus, a collection of company accounts put together by Bureau van Dijk, a commercial data provider. We use the latest version available online from July 2003. Previous editions were used by Faggio and Konings (2003) for the period 1993-1997 and by Warzynski (2003) for the period 1995-1999. Our dataset contains

\footnotetext{
${ }^{1}$ The reason for selecting these individuals is explained in the description of the econometric analysis. In a companuion paper, we analyze the selection mechanisms of candidates.
} 
information about 9133 firms from all sectors of the economy and covers the period 1996-2000. The coverage of firms is improving with time and moving more and more towards a firm level census. In Belgium, for example, Bureau van Dijk provides on a separate dataset information about all firms which are legally obliged to provide company accounts to the tax authority.

To be included in Amadeus, at least one of the following three criteria must be fulfilled: number of employees larger than 15, operating revenue larger than 1.5 million euros and total assets larger than 3 million euros. These criteria have been lowered a number of times. The sample covers all medium and large firms but excludes small firms which are likely to be more dynamic. This might lead to a downward bias in job creation. Unfortunately, we were not able to get access to census data to improve the accuracy of our variables. However, the bias is likely to be small as these firms represent the largest share of job flows, by construction of the variables (see next subsection).

\subsection{Regional job flows}

Using the firm level dataset, we compute our job flows measure by regional unit and by year. Job flows can be computed at different levels of aggregation. We start by creating our variables at the level of the voivodship.

Following Davis and Haltiwanger (1992), our job flows variables are defines as follows:

- The job creation rate in voivodship $J$ at time $t\left(P O S_{J T}\right)$ is equal to the sum of employment gains in expanding firms divided by the size divided by total employment (an average between $t$ and $t-1$ ):

$$
P O S_{J T}=\frac{\sum_{i \in J^{+}}\left(n_{i t}-n_{i(t-1)}\right)}{\sum_{i \in J} s_{i t}}
$$

where $i$ is a firm index, $J^{+}$is the subset of expanding firms in $J, n$ is employment and $s_{i t}=\frac{n_{i t}+n_{i(t-1)}}{2}$

- The job destruction rate in voivodship $J$ at time $t\left(N E G_{J T}\right)$ is equal to the sum of employment losses in contracting firms divided by the size divided by total employment: 


$$
N E G_{J T}=\frac{\left|\sum_{i \in J^{-}}\left(n_{i t}-n_{i(t-1)}\right)\right|}{\sum_{i \in J} s_{i t}}
$$

where $J^{-}$is the subset of contracting firms.

- The gross job reallocation rate $\left(G R O S S_{J t}\right)$ is the sum of the job creation rate and the job destruction rate. This is a first summary measure of Schumpeterian growth, as it reflects simultaneous job creation and job destruction.

- The net job reallocation rate $\left(N E T_{J t}\right)$ is the difference between the job creation rate and the job destruction rate. This measure provides a useful summary to determine whether creation dominates destruction in the subset and to quantify it.

- The excess job reallocation rate $\left(E X C E S S_{J t}\right)$ is the difference between the gross job reallocation rate and the absolute value of the net job reallocation rate. This is the share of job reallocation in excess of the amount required to accommodate net employment change. This is the most appropriate index of simultaneous job creation and job destruction or Schumpeterian growth. This measure does not increase with NET while GROSS does.

\section{$<$ Insert table 3>}

Table 3 shows the average job flows by voivodship over the period 19972000. One striking result is that job destruction dominates job creation in all subsets. Job destruction rates are the highest in Slaskie near the Slovak border and in Podkarpackie, a region bordering Ukraine in the South East of Poland. Net job reallocation is higher for the central and Western regions.

One problem is that these voivodships are large and heterogeneous areas. To deal with this issue, we compute job flows by constituency $(j)$. It was a rather difficult task to merge the zip codes and names of the towns (Amadeus classification) on the one hand, with the gmynia codes and names of the gmynia on the other, which are subunits of the okreg. In most cases, the name of the gmynia was also the name of the town. However, for the others, we had to look at the zip codes, link it to a database of the Polish Post to 
find out the powiat (another subregion and larger than the gmynia) and the voivodship where the firm was located.

Table 4 presents the average job flows by constituency.

$<$ Insert table $4>$

Once we look at more disaggregated areas, we notice important variations within voivodship. We also see that some constituencies have been more creative than destructive, for example the area around Warsaw (okreg 20) and the Poznan area (okreg 39).

This will also be our unit of analysis, as these sub-areas define the electoral areas. The only difference will be the time dimension, as we use the job flows by year instead of the averages over 1997-2000 used in table 4 .

\section{Empirical methodology}

\subsection{Votes by constituency}

Our first specification tests the effect of job flows in constituency $j$ on the share of the seats gained by the SLD in constituency $j\left(V_{S L D, j}\right)$ during the 2001 elections. Our aim is simply to look at whether the economic situation in a region influences the votes for the opposition party, considered as one (absolute) dimension of the vote.

$$
V_{S L D, j}=f\left(P O S_{j}, N E G_{j}, X_{J}\right)
$$

where $j$ is an index for the constituency, $J$ is an index for the voivodship and $X$ is a group of control variables.

We also use seemingly unrelated regressions (SUR) technique to look at the effect of job flows on the votes for the different parties.

$$
V_{p, j}=f\left(P O S_{j}, N E G_{j}, X_{J}\right)
$$

where $p$ is a party index. We only consider parties which obtained seats in the 2001 elections (see section 3).

The variables used as controls are the share of population aged between 20 and 40 years, the share of the population older than 60 years old, the 
$\log$ of density of population, the log of value added by capita and the unemployment rate in 2000 and 1999. All the controls are used at the level of the voivodship.

\subsection{Votes for individuals}

The second type of analysis that we carry on is to test whether the votes for a given candidate ( $V_{i j t}$, where $i$ is an individual index, $t=1997,2001$ is the year of two waves of elections) depends on the job creation and job destruction rates in his constituency. Assuming that there is a fixed component (talent, fixed trust, fixed image) in the error term, we first-differentiate the equation and look at the change in votes for candidate $i\left(\Delta V_{i j}\right)$. Therefore, we only consider those individuals who ran for elections in 1997 and 2001.

There is another important reason to consider votes for individuals rather than votes for parties. In Poland, the party system is probably less coherent than in well established Western democracies, and personality might receive more weight in the voter's decision. Controlling for the fixed element of personality, we can measure the effect of party affiliation and responsibility in previous decision making.

We look at the effect of the change of job reallocation on the change in votes for candidates. However, change in job reallocation should not affect all candidates in the same way. Indeed, individuals who are more likely to be affected by the change in economic situation in the constituency are those who were responsible for the economic situation during the period, i.e. those politicians previously elected (Incumbent). Moreover, we can take the hypothesis that incumbents will be treated differently whether they were members of the ruling coalition (Right1997) than if they were members of the opposition. We use excess job reallocation as a measure of restructuring in the constituency. As mentioned earlier, this is the most appropriate index of creative destruction, and the one which is more linked to the change in votes for individuals.

We run the following regression:.

$$
\Delta V_{i j}=f\left(\Delta E X C E S S_{j} * \text { Incumbent } * \text { Right } 97, \Delta X_{i j}, X_{i j}^{\prime}\right)
$$

where the control variables used are Incumbent, Incumbent $*$ Right1997, 
Right1997, party dummies and the change in the place on the party list. Moreover, to control for the change in the size of the constituencies, we add a variable equal to the change of registered voters in the area ${ }^{2}$.

\section{Results}

\subsection{Votes by constituency}

Result from the estimation of Eq. (1) are presented in table 5. We see that job creation and job destruction rates have a strong impact on the votes for the SLD in the constituency. Job creation has a strong negative effect on the votes for the SLD, while job destruction has a strong and positive effect. The unemployment rate at the level of the voivodship also has a positive effect on the votes for the left. The share of population between 20 and 40 years old and the share of individuals older than 60 years old have strong negative effects on the votes for the left, but variations across regions are very small, what might explain the large values of the coefficients. The $\log$ of density and the log of value added per capital also have a positive effect, what could be considered as counter-intuitive. However, the SLD has sometimes received the image of an urban party.

\section{$<$ Insert table 5>}

Table 6 shows the SUR results. Results for the SLD are unchanged. PO, PiS and LPR were more likely to receive votes in areas with high job creation and/or low job destruction, confirming their image as liberal pro-reform parties or more generally as opposition to the SLD-UP. SO on the other hand followed the same pattern than the SLD, but with less intensity, indicating that it was also able to attract those disappointed or harmed by the social consequences of reforms, in line with its populist image. Finally, votes for the PSL were relatively unaffected by job flows in the constituency, and only negatively related to density, value added per capital and unemployment.

\footnotetext{
${ }^{2}$ By doing this, we only consider one dimension of the effect of the constituency change. The composition of the constituency and the quality of the opponents might have been affected too. We were not able to find composition data at the level of the constituency. We consider the strategic individual and party decisions whether and where to run for election in our companion paper.
} 
There are many problems associated with this specification. First, the number of observations is very small. There are only 41 observations, and it is quite difficult to add in some dynamics because of the change. Second, most of the control variables are at the level of the voivoidship, while the vote data and the job flows data are at the level of the constituency. We could improve our analysis by adding information on the subregions. However, the exact composition of these is not very clear. Third, there could be a fixed regional effect that could be correlated with our right hand side variables. To tackle this issue, we would need a dynamic panel.

There are several solutions to deal with these limitations. First, one could look at more disaggregated regional subsets, like powiats or even gminas, which would have been unaffected by the reform. Votes by party are available at the level of the vote office for the 2001 elections, and therefore also at the level of the gmynia and powiat. Problems come from the right hand side variables. We could find control variables at the level of the powiat only for a limited amount of voivodships. Moreover, it is not clear whether votes by party are available at a very disaggregated level for the 1997 elections as well. Finally, once we look at very small subregional units, it would be wiser to consider a census of plants rather than the subset used in the paper.

The second solution that we follow in the next subsection is to analyze the votes for individuals, controlling for the fact that the constituencies have changed. By doing it, we increase the number of observations, we can control for (in that case individual) fixed effect, and our results are relatively unaffected by the change in the regional classification.

\subsection{Votes for individuals}

Result from the estimation of Eq. (3) are presented in table 7. The most important finding for our analysis is that incumbents from the previous coalition were less likely to be penalized if excess job reallocation was low in the constituency. This appears to indicate that the extent of restructuring in the region affects voting behavior. We also comment on the coefficients of the control variables. First of all, we see that the voters have strongly punished the members from the past ruling coalition, as shown by the coef- 
ficient of RIGHT1997. Second, individuals in most parties have on average received less votes than compared to the SLD, who were considered by the average voter as the most credible contestant. Third, elected people are more likely to receive more votes, except if they were affiliated with the previous coalition. Fourth, the change in the list place has a negative effect on the votes, meaning that moving up the list has a positive effect on the votes. Finally, the change in the size of the constituencies has a positive effect on the change in votes for individuals.

\section{$<$ Insert table $7>$}

It is not entirely clear in our analysis whether we should use the change in excess job reallocation or simply the level. We used the level in our previous specification to keep a coherent approach when comparing our two empirical strategies, at the level of the constituency and at the individual level. However, we also used the level of excess job reallocation in Eq. (3) and obtained similar results.

To sum up, our results suggest that the Schumpeterian growth process strongly affects the electoral outcome. Voters punish the incumbents if the economic situation in the constituency has deteriorated. Job creation and job destruction matter as they affect the employment and therefore well being of the voters.

\section{Conclusion}

In this paper, we have linked the evolution of the labor market to the votes for the left wing party in a voting area, and to the votes for candidates. In our regional analysis, we have found that job creation has a negative effect on the votes for the left wing party while job destruction has the opposite effect. Moreover, high unemployment rate was also associated with more votes for the left. This suggests that voters are more likely to vote for a new ruling party when the previous one has not delivered results in terms of new jobs.

We have stressed the econometric limitations of our first approach, which are partly due to the change in the regional classification in Poland. Our second approach can be seen as more promising and corrects for many of the 
problems in the regional analysis. We have analyzed the votes for individuals candidates and have found that the votes for incumbents of the previous right wing coalition were lower when excess job reallocation had increased.

This paper therefore shows that, while job flows are often part of a productivity enhancing process and are often necessary and unavoidable, they also have social consequences on the well being of the voters, who themselves punish those considered as responsible for their hardships. Therefore, a logical conclusion to be drawn from our exercise is that political constraints have to be taken into account by the government when designing its policy, suggesting that gradualism will often be a more appropriate policy for a politician motivated by reelection concerns. A balance between creating new jobs and destroying the old is the key to new success.

There are several additional interesting issues to look at, that do not necessarily concern the Schumpeterian process but rather the dynamics of voting together with career decisions.

Returns to mobility and determinants of party change Before the elections, the coalition in power collapsed and many high profile leaders left the AWS and the UW to form their own parties (PO), and others joined new formations. These party changes were probably motivated by differences of opinion, but also by career and reelection motivations.

More generally, entry and exit have occurred in all parties. We plan to analyze precisely who decided to change parties, what were the motivations for this move; and second, to test whether the strategy provided a return.

Strategic responses by parties and candidates There are other strategic choices that can be taken by parties or candidates. The party can decide about the constituency where each candidate will contest (depending on the strength of the opponents), the place on the party list. Candidates on the other hand can decide whether to run or not, depending on their chances of reelection and on their outside option.

We examine these issues more in details in a companion paper (Smeets and Warzynski, 2003). 


\section{References}

[1] Faggio, G. and Konings, J. (2003), Job creation, job destruction and employment growth in transition countries in the 90s, Economic Systems, 27,129-154.

[2] Fidrmuc, J. (2000), Political support for reforms: Economics of voting in transition countries, European Economic Review, 44, 1491-1513.

[3] Jackson, J. E., Klich, J. and Poznańska, K. (2003), Economic transition and elections in Poland, Economics of Transition, 41-66.

[4] Millard, F. (2002), Elections in Poland 2001: Party chaos and electoral manipulation, Paper presented at teh BASEES Annual Conference, Cambridge, April 8, 2002.

[5] Smeets, V. and Warzynski, F. (2003), Strategic Politicians and the Dynamics of Voting, work in progress.

[6] Warzynski, F. (2003), The causes and consequences of sector-level job flows in Poland, Economics of Transition,11, 357-381. 
TABLE 1: REGISTERED UNEMPLOYMENT RATE BY SUBREGIONS IN 1998 - 2000 As of 31 XII

\begin{tabular}{|c|c|c|c|}
\hline \multirow{2}{*}{ VOIVODSHIPS/SUBREGIONS } & 1998 & 1999 & 2000 \\
\hline & \multicolumn{3}{|c|}{ in $\%$} \\
\hline POLAND & 10,4 & 13,1 & 15,1 \\
\hline DOLNOŚLĄSKIE & 12,8 & 16,0 & 18,4 \\
\hline Jeleniogórsko-wałbrzyski & 17,1 & 21,0 & 23,7 \\
\hline Legnicki & 14,0 & 17,6 & 19,3 \\
\hline Wrocławski & 6,9 & 9,1 & 19,3 \\
\hline m. /city/ Wrocław & $\mathrm{x}$ & $\mathrm{x}$ & 7,4 \\
\hline KUJAWSKO-POMORSKIE & 13,9 & 16,9 & 19,2 \\
\hline Bydgoski & 13,0 & 15,6 & 17,9 \\
\hline Toruńsko-włocławski & 14,9 & 18,2 & 20,4 \\
\hline LUBELSKIE & 10,3 & 12,9 & 14,0 \\
\hline Bialskopodlaski & 10,9 & 13,7 & 14,8 \\
\hline Chełmsko-zamojski & 11,1 & 14,0 & 14,7 \\
\hline Lubelski & 9,7 & 12,1 & 13,4 \\
\hline LUBUSKIE & 13,2 & 17,5 & 21,3 \\
\hline Gorzowski & 11,3 & 15,2 & 19,5 \\
\hline Zielonogórski & 14,5 & 18,9 & 22,4 \\
\hline LÓDZKIE & 11,4 & 14,3 & 16,3 \\
\hline Łódzki & 4,1 & 5,4 & 16,7 \\
\hline Piotrkowsko-skierniewicki & 12,2 & 14,9 & 16,3 \\
\hline m./city/ Łódź & $\mathrm{x}$ & $\mathrm{x}$ & 15,8 \\
\hline MALOPOLSKIE & 7,6 & 10,2 & 12,2 \\
\hline Krakowsko-tarnowski & 6,3 & 8,8 & 13,4 \\
\hline Nowosądecki & 10,1 & 12,9 & 14,8 \\
\hline m. /city/ Kraków & $\mathrm{x}$ & $\mathrm{x}$ & 6,5 \\
\hline MAZOWIECKIE & 7,6 & 9,5 & 10,8 \\
\hline Ciechanowsko-płocki & 14,1 & 16,8 & 19,1 \\
\hline Ostrołęcko-siedlecki & 12,1 & 14,3 & 15,9 \\
\hline Warszawski & 1,0 & 1,2 & 10,8 \\
\hline Radomski & 15,2 & 18,6 & 20,3 \\
\hline $\mathrm{m}$. /city/ Warszawa & $\mathrm{x}$ & $\mathrm{x}$ & 3,2 \\
\hline OPOLSKIE & 10,5 & 13,2 & 15,7 \\
\hline Opolski & 10,5 & 13,2 & 15,7 \\
\hline PODKARPACKIE & 12,3 & 14,5 & 16,2 \\
\hline Rzeszowsko-tarnobrzeski & 11,8 & 13,7 & 15,2 \\
\hline Krośnieńsko-przemyski & 12,9 & 15,4 & 17,3 \\
\hline PODLASKIE & 10,8 & 12,5 & 13,8 \\
\hline Białostocko-suwalski & 9,9 & 11,7 & 12,9 \\
\hline Łomżyński & 13,5 & 15,0 & 16,3 \\
\hline POMORSKIE & 11,0 & 13,8 & 16,6 \\
\hline Słupski & 19,6 & 23,1 & 26,4 \\
\hline Gdański & 2,7 & 3,4 & 20,1 \\
\hline Gdańsk-Gdynia-Sopot & $\mathrm{x}$ & $\mathrm{x}$ & 6,7 \\
\hline ŚLĄSKIE & 7,3 & 10,4 & 12,9 \\
\hline Północnośląski & 8,9 & 12,4 & 14,6 \\
\hline Południowoślaski & 6,3 & 9,2 & 11,6 \\
\hline Centralny śląski & 7,2 & 10,4 & 13,1 \\
\hline ŚWIĘTOKRZYSKIE & 12,1 & 15,1 & 16,6 \\
\hline Świętokrzyski & 12,1 & 15,1 & 16,6 \\
\hline WARMIŃSKO-MAZURSKIE & 19,7 & 22,4 & 25,8 \\
\hline Elbląski & 19,4 & 22,8 & 27,1 \\
\hline Olsztyński & 17,4 & 19,4 & 22,4 \\
\hline Ełcki & 25,3 & 28,1 & 31,1 \\
\hline WIELKOPOLSKIE & $\mathbf{8 , 0}$ & 10,5 & 12,5 \\
\hline
\end{tabular}

Source: Polish Statistical Office 
Table 2: Results of the 2001 Sejm Elections

\begin{tabular}{|c|c|c|}
\hline Party & Number of seats & \% of seats \\
\hline \hline SLD-UP & 216 & 46.96 \\
\hline PO & 65 & 14.13 \\
\hline SO & 53 & 11.52 \\
\hline PiS & 44 & 9.56 \\
\hline PSL & 42 & 9.13 \\
\hline LPR & 38 & 8.26 \\
\hline German Minority & 2 & 0.43 \\
\hline \hline Total & $\mathbf{4 6 0}$ & $\mathbf{1 0 0}$ \\
\hline
\end{tabular}

SLD-UP: Alliance of the Democratic Left-Labor Union (Sojusz Lewicy Demokratycznej-Unia Pracy)

PO: Civic Platform (Platforma Obywatelska)

SO: Self Defense (Samoobrona)

PiS: Law and Justice (Prawo i Sprawiedliwosc)

PSL: Polish Peasant Party (Polskie Stronnictwo Ludowe)

LPR: League of Polish Families (Liga Polskich Rodzin)

Source: Millard (2002) 
Table 3: average job flows by voivodship (1997-2000)

\begin{tabular}{|c|c|c|c|c|c|}
\hline Voivodship & POS & NEG & NET & GROSS & EXCESS \\
\hline \hline Dolnoslaskie & 0.052 & 0.082 & -0.031 & 0.134 & 0.103 \\
\hline Kujawsko-Pomorskie & 0.044 & 0.070 & -0.026 & 0.114 & 0.088 \\
\hline Lubelskie & 0.025 & 0.076 & -0.052 & 0.101 & 0.049 \\
\hline Lubuskie & 0.039 & 0.075 & -0.036 & 0.114 & 0.078 \\
\hline Lodzkie & 0.040 & 0.072 & -0.032 & 0.111 & 0.079 \\
\hline Malopolskie & 0.052 & 0.083 & -0.031 & 0.135 & 0.104 \\
\hline Mazowieckie & 0.049 & 0.070 & -0.020 & 0.119 & 0.098 \\
\hline Opolskie & 0.033 & 0.078 & -0.045 & 0.111 & 0.067 \\
\hline Podkarpackie & 0.045 & 0.102 & -0.057 & 0.147 & 0.090 \\
\hline Podlaskie & 0.038 & 0.074 & -0.036 & 0.112 & 0.075 \\
\hline Pomorskie & 0.044 & 0.055 & -0.011 & 0.099 & 0.087 \\
\hline Slaskie & 0.031 & 0.103 & -0.072 & 0.134 & 0.062 \\
\hline Swietokrzyskie & 0.043 & 0.088 & -0.045 & 0.131 & 0.087 \\
\hline Warminsko-Mazurskie & 0.032 & 0.074 & -0.042 & 0.106 & 0.064 \\
\hline Wielkopolskie & 0.068 & 0.075 & -0.008 & 0.143 & 0.136 \\
\hline Zachodniopomorskie & 0.040 & 0.060 & -0.020 & 0.100 & 0.080 \\
\hline
\end{tabular}


Table 4: average job flows by constituency (1997-2000)

\begin{tabular}{|c|c|c|c|c|c|c|}
\hline Voivodship & Okreg & POS & $\overline{N E G}$ & NET & GROSS & EXCESS \\
\hline \multirow{3}{*}{ Dolnoslaskie } & 1 & 0.028 & 0.065 & -0.037 & 0.093 & 0.056 \\
\hline & 2 & 0.031 & 0.102 & -0.071 & 0.133 & 0.062 \\
\hline & 3 & 0.078 & 0.088 & -0.010 & 0.166 & 0.156 \\
\hline \multirow{2}{*}{ Kujawsko-Pomorskie } & 4 & 0.034 & 0.067 & -0.033 & 0.102 & 0.069 \\
\hline & 5 & 0.053 & 0.072 & -0.019 & 0.126 & 0.107 \\
\hline \multirow{2}{*}{ Lubelskie } & 6 & 0.026 & 0.075 & -0.049 & 0.101 & 0.052 \\
\hline & 7 & 0.022 & 0.080 & -0.058 & 0.101 & 0.043 \\
\hline Lubuskie & 8 & 0.039 & 0.075 & -0.036 & 0.114 & 0.078 \\
\hline \multirow{3}{*}{ Lodzkie } & 9 & 0.050 & 0.083 & -0.033 & 0.132 & 0.099 \\
\hline & 10 & 0.033 & 0.057 & -0.024 & 0.089 & 0.066 \\
\hline & 11 & 0.033 & 0.075 & -0.043 & 0.108 & 0.066 \\
\hline \multirow{4}{*}{ Malopolskie } & 12 & 0.031 & 0.077 & -0.046 & 0.109 & 0.062 \\
\hline & 13 & 0.068 & 0.087 & -0.019 & 0.155 & 0.136 \\
\hline & 14 & 0.017 & 0.093 & -0.077 & 0.110 & 0.033 \\
\hline & 15 & 0.032 & 0.058 & -0.026 & 0.091 & 0.064 \\
\hline \multirow{5}{*}{ Mazowieckie } & 16 & 0.048 & 0.065 & -0.017 & 0.113 & 0.096 \\
\hline & 17 & 0.039 & 0.093 & -0.054 & 0.133 & 0.078 \\
\hline & 18 & 0.032 & 0.058 & -0.026 & 0.090 & 0.064 \\
\hline & 19 & 0.047 & 0.070 & -0.022 & 0.117 & 0.095 \\
\hline & 20 & 0.090 & 0.066 & 0.024 & 0.156 & 0.132 \\
\hline Opolskie & 21 & 0.033 & 0.078 & -0.045 & 0.111 & 0.067 \\
\hline \multirow{2}{*}{ Podkarpackie } & 22 & 0.025 & 0.084 & -0.059 & 0.108 & 0.049 \\
\hline & 23 & 0.053 & 0.109 & -0.056 & 0.163 & 0.106 \\
\hline Podlaskie & 24 & 0.038 & 0.074 & -0.036 & 0.112 & 0.075 \\
\hline \multirow{2}{*}{ Pomorskie } & 25 & 0.048 & 0.056 & -0.009 & 0.104 & 0.096 \\
\hline & 26 & 0.039 & 0.053 & -0.014 & 0.092 & 0.078 \\
\hline \multirow{6}{*}{ Slaskie } & 27 & 0.045 & 0.103 & -0.058 & 0.149 & 0.091 \\
\hline & 28 & 0.040 & 0.089 & -0.048 & 0.129 & 0.081 \\
\hline & 29 & 0.021 & 0.117 & -0.096 & 0.138 & 0.042 \\
\hline & 30 & 0.015 & 0.078 & -0.062 & 0.093 & 0.031 \\
\hline & 31 & 0.035 & 0.110 & -0.075 & 0.146 & 0.071 \\
\hline & 32 & 0.031 & 0.111 & -0.080 & 0.142 & 0.062 \\
\hline Swietokrzyskie & 33 & 0.043 & 0.088 & -0.045 & 0.131 & 0.087 \\
\hline \multirow{2}{*}{ Warm insko-Mazurskie } & 34 & 0.031 & 0.084 & -0.054 & 0.115 & 0.062 \\
\hline & 35 & 0.034 & 0.058 & -0.024 & 0.092 & 0.068 \\
\hline \multirow{4}{*}{ W ielkopolskie } & 36 & 0.045 & 0.083 & -0.038 & 0.128 & 0.090 \\
\hline & 37 & 0.030 & 0.088 & -0.058 & 0.118 & 0.060 \\
\hline & 38 & 0.051 & 0.059 & -0.008 & 0.111 & 0.103 \\
\hline & 39 & 0.098 & 0.074 & 0.024 & 0.172 & 0.148 \\
\hline \multirow{2}{*}{ Zachodniopomorskie } & 40 & 0.035 & 0.064 & -0.029 & 0.098 & 0.069 \\
\hline & 41 & 0.042 & 0.058 & -0.016 & 0.101 & 0.085 \\
\hline
\end{tabular}


Table 5: determinants of the votes for the SLD by constituency (OLS estimation)

\begin{tabular}{|c|cc|}
\hline Dep. var.: $V_{S L D, j}$ & & \\
\hline \hline POS $_{j}$ in 2000 & $-1.45^{* *}$ & $(0.66)$ \\
\hline NEG $_{j}$ in 1999 & $1.48^{* * *}$ & $(0.45)$ \\
\hline (Share pop.between 20 and $40 y.)_{J}$ & $-10.76^{* *}$ & $(4.04)$ \\
\hline$(\text { Share pop. older than } 60 \text { y. })_{J}$ & $-7.31^{* * *}$ & $(2.13)$ \\
\hline $\log ($ Density $J)$ & $0.08^{* *}$ & $(0.03)$ \\
\hline$\left[\log (\text { VA/capita }]_{J}\right.$ & $0.13^{*}$ & $(0.07)$ \\
\hline Unemployment $_{J}$ in 1999 & $1.22^{* *}$ & $(0.58)$ \\
\hline constant & $2.90^{*}$ & $(1.74)$ \\
\hline Adj.R & \multicolumn{2}{|c|}{0.60} \\
\hline Nr. Obs. & \multicolumn{2}{|c|}{41} \\
\hline
\end{tabular}

Note: standard errors in parentheses; $* * * / * * / *$ indicate statistical significances respectively at the $1 \% / 5 \% / 10 \%$ confidence level 


\section{Table 6: SUR results}

\begin{tabular}{|c|c|c|c|c|c|c|}
\hline Dep. var.: $V_{S L D, j}$ & SLD & SO & PiS & PSL & PO & LPR \\
\hline \hline POS $_{j}$ in 2000 & $-1.45^{* *}(0.66)$ & $-0.79^{*}(0.43)$ & $1.01^{* *}(0.45)$ & $-0.36(0.58)$ & $0.77^{*}(0.42)$ & $0.94^{* * *}(0.32)$ \\
\hline NEG $_{j}$ in 1999 & $1.48^{* * *}(0.45)$ & $0.50^{*}(0.29)$ & $-0.93^{* * *}(0.30)$ & $-0.15(0.39)$ & $-0.55^{* *}(0.28)$ & $-0.50^{* *}(0.21)$ \\
\hline (Share pop.between 20 and $\left.40 y_{.}\right)_{J}$ & $-10.76^{* *}(4.04)$ & $-1.45(2.62)$ & $2.56(2.74)$ & $-1.35(3.50)$ & $2.33(2.52)$ & $3.39^{*}(1.92)$ \\
\hline${\left.\text { (Share pop. older than } 60 \mathrm{y}_{J}\right)_{J}}$ & $-7.31^{* * *}(2.13)$ & $-0.19(1.37)$ & $1.54(1.44)$ & $1.50(1.84)$ & $-0.33(1.33)$ & $2.24^{* *}(1.01)$ \\
\hline $\log ($ Density $J)$ & $0.08^{* *}(0.03)$ & $-0.02(0.02)$ & $0.02(0.02)$ & $-0.08^{* * *}(0.03)$ & $0.05^{* * *}(0.02)$ & $-0.03^{* *}(0.01)$ \\
\hline$\left[\log (\mathrm{VA} / \text { capita }]_{J}\right.$ & $0.13^{*}(0.07)$ & $0.05(0.03)$ & $0.03(0.05)$ & $-0.12^{*}(0.07)$ & $0.05(0.05)$ & $0.09^{* * *}(0.04)$ \\
\hline Unemployment $_{J}$ in 1999 & $1.22^{* *}(0.52)$ & $-0.003(0.37)$ & $-0.08(0.39)$ & $-1.27^{* *}(0.50)$ & $0.09(0.36)$ & $-0.23(0.27)$ \\
\hline constant & $2.90^{*}(1.74)$ & $0.91(1.26)$ & $-1.20(1.31)$ & $1.96(1.68)$ & $-1.20(1.21)$ & $-0.18(0.92)$ \\
\hline
\end{tabular}

Note: see table 5 
Table 7: determinants of the change in votes for candidates (OLS estimation)

\begin{tabular}{|c|cc|}
\hline Dep. var.: $\Delta V_{i j}$ & & \\
\hline \hline Change in registered voters & $0.003^{* * *}$ & $(0.001)$ \\
\hline Incumbent & $2467.87^{* * *}$ & $(837.82)$ \\
\hline Incumbent*Right1997 & $-10650.82^{* * *}$ & $(1322.72)$ \\
\hline Right1997 & $-2292.24^{* * *}$ & $(848.3)$ \\
\hline Change in the place on the party list & $-202.33^{* * *}$ & $(34.00)$ \\
\hline$\Delta E X C E S S_{j} *$ Incumbent $*$ Right 97 & $-43432.17^{* * *}$ & $(16092.11)$ \\
\hline Party dummies & \multicolumn{2}{|c|}{ YES } \\
\hline Adj.R & \multicolumn{2}{|c|}{0.23} \\
\hline Nr. Obs. & \multicolumn{2}{|c|}{1192} \\
\hline
\end{tabular}

Note: see table 3 
Figure 1: Evolution of the Unemployment rate in Poland (January 1990-June 2003)

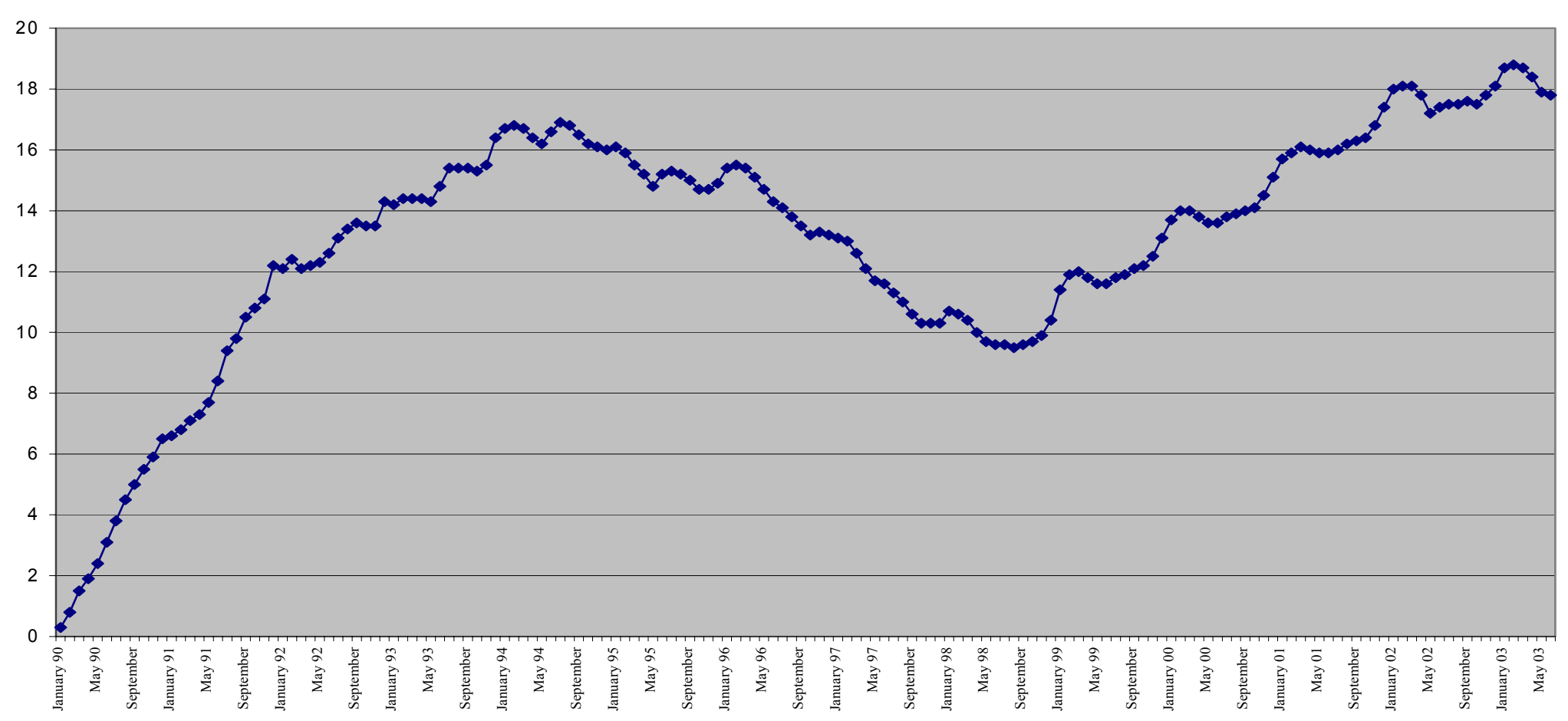

Source: Polish Statistical Office 
Department of Economics:

Skriftserie/Working Paper:

2002:

WP 02-1 Peter Jensen, Michael Rosholm and Mette Verner: A Comparison of Different Estimators for Panel Data Sample Selection Models. ISSN 1397-4831.

WP 02-2 Erik Strøjer Madsen, Camilla Jensen and Jørgen Drud Hansen: Scale in Technology and Learning-by-doing in the Windmill Industry. ISSN 1397-4831.

WP 02-3 Peter Markussen, Gert Tinggaard Svendsen and Morten Vesterdal: The political economy of a tradable GHG permit market in the European Union. ISSN 13974831 .

WP 02-4 Anders Frederiksen og Jan V. Hansen: Skattereformer: Dynamiske effekter og fordelingskonsekvenser. ISSN 1397-4831.

WP 02-5 Anders Poulsen: On the Evolutionary Stability of Bargaining Inefficiency. ISSN $1397-4831$.

WP 02-6 Jan Bentzen and Valdemar Smith: What does California have in common with Finland, Norway and Sweden? ISSN 1397-4831.

WP 02-7 Odile Poulsen: Optimal Patent Policies: A Survey. ISSN 1397-4831.

WP 02-8 Jan Bentzen and Valdemar Smith: An empirical analysis of the interrelations among the export of red wine from France, Italy and Spain. ISSN 1397-4831.

WP 02-9 A. Goenka and O. Poulsen: Indeterminacy and Labor Augmenting Externalities. ISSN 1397-4831.

WP 02-10 Charlotte Christiansen and Helena Skyt Nielsen: The Educational Asset Market: A Finance Perspective on Human Capital Investment. ISSN 1397-4831.

WP 02-11 Gert Tinggaard Svendsen and Morten Vesterdal: CO2 trade and market power in the EU electricity sector. ISSN 1397-4831.

WP 02-12 Tibor Neugebauer, Anders Poulsen and Arthur Schram: Fairness and Reciprocity in the Hawk-Dove game. ISSN 1397-4831.

WP 02-13 Yoshifumi Ueda and Gert Tinggaard Svendsen: How to Solve the Tragedy of the Commons? Social Entrepreneurs and Global Public Goods. ISSN 1397-4831.

WP 02-14 Jan Bentzen and Valdemar Smith: An empirical analysis of the effect of labour market characteristics on marital dissolution rates. ISSN 1397-4831. 
WP 02-15 Christian Bjørnskov and Gert Tinggaard Svendsen: Why Does the Northern Light Shine So Brightly? Decentralisation, social capital and the economy. ISSN 13974831 .

WP 02-16 Gert Tinggaard Svendsen: Lobbyism and $\mathrm{CO}_{2}$ trade in the EU. ISSN 1397-4831.

WP 02-17 Søren Harck: Reallønsaspirationer, fejlkorrektion og reallønskurver. ISSN 13974831.

WP 02-18 Anders Poulsen and Odile Poulsen: Materialism, Reciprocity and Altruism in the Prisoner's Dilemma - An Evolutionary Analysis. ISSN 1397-4831.

WP 02-19 Helena Skyt Nielsen, Marianne Simonsen and Mette Verner: Does the Gap in Family-friendly Policies Drive the Family Gap? ISSN 1397-4831.

2003:

WP 03-1 Søren Harck: Er der nu en strukturelt bestemt langsigts-ledighed I SMEC?: Phillipskurven i SMEC 99 vis-à-vis SMEC 94. ISSN 1397-4831.

WP 03-2 Beatrice Schindler Rangvid: Evaluating Private School Quality in Denmark. ISSN 1397-4831.

WP 03-3 Tor Eriksson: Managerial Pay and Executive Turnover in the Czech and Slovak Republics. ISSN 1397-4831.

WP 03-4 Michael Svarer and Mette Verner: Do Children Stabilize Marriages? ISSN 13974831 .

WP 03-5 Christian Bjørnskov and Gert Tinggaard Svendsen: Measuring social capital - Is there a single underlying explanation? ISSN 1397-4831.

WP 03-6 Vibeke Jakobsen and Nina Smith: The educational attainment of the children of the Danish 'guest worker' immigrants. ISSN 1397-4831.

WP 03-7 Anders Poulsen: The Survival and Welfare Implications of Altruism When Preferences are Endogenous. ISSN 1397-4831.

WP 03-8 Helena Skyt Nielsen and Mette Verner: Why are Well-educated Women not Fulltimers? ISSN 1397-4831.

WP 03-9 Anders Poulsen: On Efficiency, Tie-Breaking Rules and Role Assignment Procedures in Evolutionary Bargaining. ISSN 1397-4831.

WP 03-10 Anders Poulsen and Gert Tinggaard Svendsen: Rise and Decline of Social Capital - Excess Co-operation in the One-Shot Prisoner's Dilemma Game. ISSN 13974831 . 
WP 03-11 Nabanita Datta Gupta and Amaresh Dubey: Poverty and Fertility: An Instrumental Variables Analysis on Indian Micro Data. ISSN 1397-4831.

WP 03-12 Tor Eriksson: The Managerial Power Impact on Compensation - Some Further Evidence. ISSN 1397-4831.

WP 03-13 Christian Bjørnskov: Corruption and Social Capital. ISSN 1397-4831.

WP 03-14 Debashish Bhattacherjee: The Effects of Group Incentives in an Indian Firm - Evidence from Payroll Data. ISSN 1397-4831.

WP 03-15 Tor Eriksson och Peter Jensen: Tidsbegränsade anställninger - danska erfarenheter. ISSN 1397-4831.

WP 03-16 Tom Coupé, Valérie Smeets and Frédéric Warzynski: Incentives, Sorting and Productivity along the Career: Evidence from a Sample of Top Economists. ISSN 1397-4831.

WP 03-17 Jozef Koning, Patrick Van Cayseele and Frédéric Warzynski: The Effects of Privatization and Competitive Pressure on Firms' Price-Cost Margins: Micro Evidence from Emerging Economies. ISSN 1397-4831.

WP 03-18 Urs Steiner Brandt and Gert Tinggaard Svendsen: The coalition of industrialists and environmentalists in the climate change issue. ISSN 1397-4831.

WP 03-19 Jan Bentzen: An empirical analysis of gasoline price convergence for 20 OECD countries. ISSN 1397-4831.

WP 03-20 Jan Bentzen and Valdemar Smith: Regional income convergence in the Scandinavian countries. ISSN 1397-4831.

WP 03-21 Gert Tinggaard Svendsen: Social Capital, Corruption and Economic Growth: Eastern and Western Europe. ISSN 1397-4831.

WP 03-22 Jan Bentzen and Valdemar Smith: A Comparative Study of Wine Auction Prices: Mouton Rothschild Premier Cru Classé. ISSN 1397-4831.

WP 03-23 Peter Guldager: Folkepensionisternes incitamenter til at arbejde. ISSN 1397-4831.

WP 03-24 Valérie Smeets and Frédéric Warzynski: Job Creation, Job Destruction and Voting Behavior in Poland. ISSN 1397-4831. 